IRA-International Journal of Education \& Multidisciplinary Studies

ISSN 2455-2526; Vol.08, Issue 01 (July 2017)

Pg. no. 24-34

Institute of Research Advances

http://research-advances.org/index.php/IJEMS

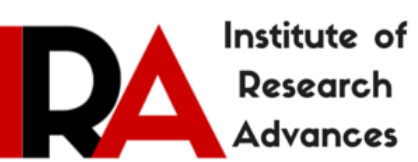

\title{
Design and Process of Learning Making Machete as a Model of Community Participation in the Democratic Learning- Based Thematic Task
}

Jeane V. Tumangkeng

Department of Physics, Faculty of Science and Mathematics, University of Manado, Indonesia.

Type of Review: Peer Reviewed.

DOI: http://dx.doi.org/10.21013/jems.v8.n1.p4

\section{How to cite this paper:}

Tumangkeng, J. (2017). Design and Process of Learning Making Machete as a Model of Community Participation in the Democratic Learning- Based Thematic Task. IRA International Journal of Education and Multidisciplinary Studies (ISSN 2455-2526), 8(1), 24-34. doi:http://dx.doi.org/10.21013/jems.v8.n1.p4

(C) Institute of Research Advances.

\section{(cc) BY-NC}

This work is licensed under a Creative Commons Attribution-Non Commercial 4.0 International License subject to proper citation to the publication source of the work.

Disclaimer: The scholarly papers as reviewed and published by the Institute of Research Advances (IRA) are the views and opinions of their respective authors and are not the views or opinions of the IRA. The IRA disclaims of any harm or loss caused due to the published content to any party.

Institute of Research Advances is an institutional publisher member of Publishers Inter Linking Association Inc. (PILA-CrossRef), USA. The institute is an institutional signatory to the Budapest Open Access Initiative, Hungary advocating the open access of scientific and scholarly knowledge. The Institute is a registered content provider under Open Access Initiative Protocol for Metadata Harvesting (OAI-PMH).

The journal is indexed \& included in WorldCat Discovery Service (USA), CrossRef Metadata Search (USA), WorldCat (USA), OCLC (USA), Open J-Gate (India), EZB (Germany) Scilit (Switzerland), Airiti (China), Bielefeld Academic Search Engine (BASE) of Bielefeld University, Germany, PKP Index of Simon Fraser University, Canada. 


\begin{abstract}
Learning that emphasize science process can be developed optimally utilizing the environment as a learning resource, as well as community involvement as a resource Community members or parents of students have the knowledge, skills and values associated with a particular form of activity, utilization of natural resources and social relationships. The process of science conducted in the environment, being a learning process that comprehensively covers the components of the knowledge, skills and values. Making traditional machete rich with knowledge and skills related to science and math concepts. This study develops science teaching junior high school that focuses on the process of making traditional machete. The experiment was conducted in the village of Gunung, District Central Tabukan, Sangihe, for six months, from March 2015 to August 2015. This study is an example of community participation in the development of students' learning process through thematic task.
\end{abstract}

Keywords: process of science, Making machete, community participation

\title{
1. Introduction
}

The fact now indicates many behaviors of young generation who do not care for the environment and environment health, forest sustainability, the preservation of coastal ecosystem etc. Previous survey in December $2012 \mathrm{~s} / \mathrm{d}$ in February 2013, showed that the school does not have a strong role for the character education of young generation, so that the younger generation does not play a role in the transformation of cultural values and local wisdoms about preserving the environment and resources. The survey December $2012 \mathrm{~s} / \mathrm{d}$ pebruari 2013, shows that the school does not have the role of powerful to character education the younger generation, so that young generation play no role in the transformation of cultural values local wisdom and about environment preservation and resources. Learning implementation in the district Manganitu thematic task shows their community initiatives for participation in learning activities in the field. The results of the interviews revealed that community members expect their learning activities that can build up an active role of students and young people as they are developed through the field activities. Schools must act as a forum for the communication of parents / society with the leadership of the school and the teachers. The role of parents and communities in the design and implementation of thematic learning becomes imperative. Parents and the community can act as a resource, facilitator or children's learning partners (Medellu, 2013). Experience in the design and implementation of the thematic task (research early 2013) shows great opportunities for the involvement of parents and community role for learning in elementary, middle and high school in the District Manganitu (Tumangkeng, J.2013).

The learning process is a system that cannot be separated from the components that are interrelated with each other. Teacher is one of the components of the system which is crucial in learning. Related to the design of learning, the teacher plays a role in creating the model of teaching models. Joyce \& Weil (1980) defines learning model as a conceptual framework that is used as a guide in learning. The conceptual framework of the learning model depicts a systematic procedure for organizing a learning experience to achieve the learning objectives. According Hamalik (2001) learning is a combination that includes elements arrayed human, material, facilities, equipment, and procedures that influence each other to achieve the learning objectives. Furthermore Mulyasa (2004) describes the learning is essentially the process of interaction between the students and the environment, resulting in a change of behavior towards the better. It was also explained that the Diverse learning resources around the lives of learners, both designed and utilized generally not fully utilized, its use is still limited to textbooks. Effective teaching puts a great emphasis on student participation in the learning process. Atilla ÇIMMER (2006) suggests that students should be active rather than passive recipients of information from teachers, computers, textbooks or other learning resources in the learning process because of the meaning constructed in the minds of students

According to the learning context, this study developed a learning environment that utilizes students and focuses on the process of making a machete. The process of making a machete contains many concepts that are relevant science and math developed as a form of thematic task to be undertaken by students outside the classroom. Learning outside the classroom enhance their knowledge and understanding of natural systems and processes ultimately establish responsibility for the environment (Higgins, 2002;Mikulec, E.,McKinney, Kathleen. 2014). According to Popov (2008), the learning context in the form of the phenomenon and the real objects in everyday life is not explicit as in the laboratory, the context must be discovered and studied. This study is part of a development / enhancement of participatory community (participative community) the community (community) who participated in the design and 
implementation of thematic learning. This research was conducted for six months (March to August 2015). Subject of learning involved in learning is student grade 7 and grade 8, junior Christian Bellae in the village of Gunung, District Central Tabukan, Sangihe. Research activities include (1) identification of the components and the process of making a machete, (2) identification of concepts of science and mathematics manufacture of machetes, (3) the formulation of matter and inquiry-based learning activities and problem solving, (4) implementation of the learning is done in groups. Process and student learning outcomes were evaluated using the format of observation and learning activities, report / portfolio groups, and the test results

\section{Objective}

Objectives: 1) Designing thematic task-based learning materials machete-making process. Design activities include: identification of components and manufacturing processes machetes, identification of concepts of science and mathematics manufacture of machetes, the formulation materials and learning activities based on inquiry, compiling indicator processes and learning goal and drafting instrument assessment / evaluation, 2) the implementation of learning design and evaluation of the learning process, 3) evaluation of the product and the achievement of learning (mastery of concepts related)

\section{Research Methods}

\section{Research Procedure}

This research is a development research that is open according to the spiral development of materials or learning activities (Sugiyono, 2008). The development of thematic task instruction is open due to adopt the principle of democratic learning materials and learning activities tailored to the experience and needs of students. Stages of research activities schematically presented in Figure-1

\section{Figure-1 Stages of research activities}

Design instructional materials thematic task: the making of machete

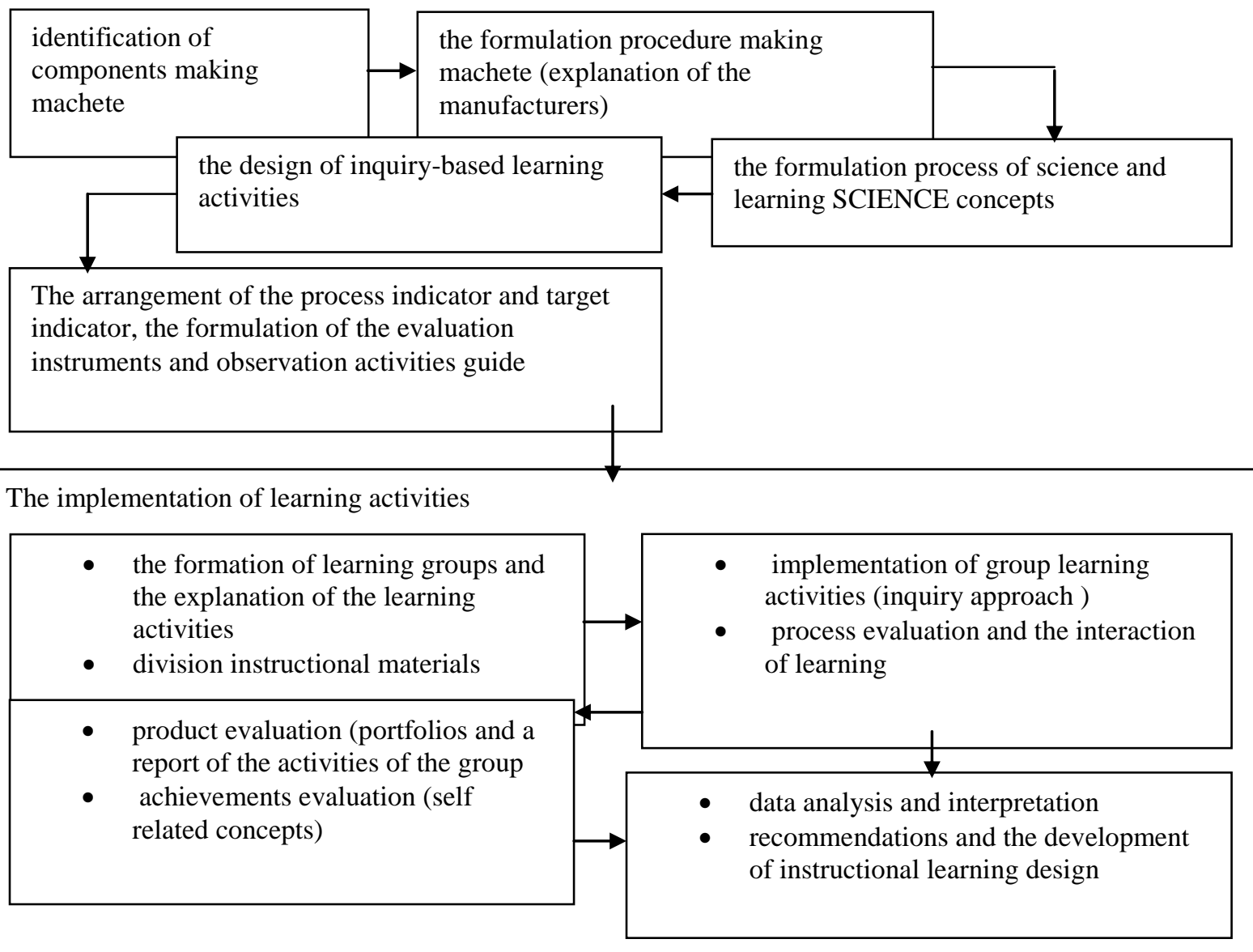




\section{The location of the research}

Was conducted in the Gunungvillage, Middle Tabukan Sub-district, Sangihe. Determination of research location in the availability of making a traditional machete and proximity of Christian junior Bellae

\section{The technique of Data Collection}

Process Data interaction of group learning and cross-group obtained using observation format that contains the indicator of learning process indicator. Product Data and learning achievements obtained through the evaluation of the group work (refer to the target indicators) and the results of the oral examination and written both individuals and groups.

\section{Analysis Techniques and The Presentation Of The Data}

The results of research are analyzed quantitatively using analysis of the proportion or percentage of students according to the classification of indicators and process indicators target. The relationship between the process with students achievements with the mastery of concepts and procedures/process of science were analyzed using the analysis of governance levels Spearman correlation rho. (Creswell,J. 2008)

\section{Research Result}

In Sangihe district, making machete (and other wrought iron products) traditionally have been almost extinct. Different from the case with traditional music tagonggong, preservation of making traditional machete did not get the support of the government program. This time, most smiths are already using a fan to exhale (supplying oxygen) on the heap coals to heat up the iron. . In the Gunung village, Middle Tabukan Sub-district, there is only one producer that makes machete with traditional way. The superiority of the making of machete by the traditional in learning is the riches of the concept of the physics associated with the system of the equipment and the process of making machete. The sequence of the process of making machete very rich concept of physics associated with the system changes energy. Through this research has established a participatory community learning making machete traditionally in mountain village, members consist of smiths, (2), the school principal and teachers SMP Christians Bellae and community leaders. Making learning development research machete in the form of tasks carried out outside the hours studying responded very well by teachers, although not a government program. Participatory community group activities making machete traditional in this research is:

a. Discuss the components of the equipment and its function, the process of making machete and various methods or traditional way to produce a good product. This discussion led by smiths,. Discussion followed by the junior high students to provide initial understanding and motivate them about the benefit of learning (tasks) making machete traditional

b. Identify the elements of learning (the concept of science and mathematics) the equipment and the process of making machete, for the formulation of learning materials. This identification was facilitated by a team of lecturers researchers from Manado state University (Unima), involve teachers and community leaders. Smiths, give comments related to the process and the various phenomena which occur in the process of making machete

c. The formulation of the instrument process evaluation and learning achievements (mastery of the context, concept, relationship with the context concept)

d. Carry out the learning activities: analyzing the function of the equipment and the concept of science and mathematics related, analyzes the process of change in energy from pumping the air until the iron warming, mechanical process to change the form of iron (with how to beat), the process of thermodynamics (Iron cooling using water and/or used oil). Main facilitator learning activities this is the craftsman or smiths,. Teachers and community leaders help facilitation of the learning activities associated with additional explanation about the relationship between the way/process with the phenomenon and related to the concept of. Researchers Team (lecturers and students) facilitate student groups in identifying the concept of networking and formulate the concept and draw up a report of the activities as well as to evaluate the process and learning achievements student groups.

The direction of school principals and teachers need to be child initiated, encourage and coordinate the function of participatory community learning making machete, with develop and implement instructional design research results. The main difficulty of participatory community is in the design of the materials and activities, especially in identifying and formulate the concept and networking concepts. The mentoring by a team of lecturers and students 
of the level of the end of the very needed a sustained, until the teachers and participatory community is able to develop and implement learning design independently. This is the needs of the school in the implementation of the curriculum and enrichment of learning resources and the integration of experience and the needs of children from outside the school to learning (knowledge, skills value) obtained in schools

\section{a. The process of making machete}

Stages a wrought iron produce machete etc. using traditional penanesaleng is as follows:

1) Prepare the pile of coals with a little fire, placed in front of the shelter.

2) The Pump angina in the tube with interest to the top and then press down the trunk of the "piston". The wind will breeze through small tube (songo) toward the pile of carry through the shelter until the burning coals

3) Take iron which will be processed into specific products, inputs in coal is burning. If needed add coals to iron become closed coals

4) The Pump the air in ontapeng, until the iron be red

5) Take bars of iron which is red using the tweezers of iron, then palu on dangsilangese or dangsilangbawine according the needs and forms delivered by

6) If the iron has cooled down, inputs the iron in the pile of coals and pump the air in ontapeng etc., until formed iron products delivered by

7) Preheat the iron that has been formed, until the redness, then never immerse to penanebuang, containing used oil. This process is called menebu. First menebu using water. According to wrought iron, menebu using oil is more secure from menebu using water, because using the oil iron is not easy cracks. If using water, menebu must be done thoroughly and could not enter the iron that is already formed simultaneously; if it does not the iron will cracks

\section{b. The scheme changes energy on making machete and other smiths, production}

Change of energy is the dominant concept in the process of making machete traditionally. An example of the arrangement of energy scheme by students is one of the alternative instructional design students to increase the mastery of concepts and procedural knowledge in the utilization of production process machete and other iron products. An example of the design of learning activities to arrange the scheme based on the components and the sequence (work procedures can also be used for the formulation of the concept of the scheme and networking other concept. Below are presented the parts from the scheme changes energy in the process of making machete. Examples of Instructions: (1) organized the sequence changes energy according to the process of making the recommendation and (2) Give the arrow between the box that you row to show the sequence of the process of energy changes

\section{Figure-2. Scheme changes energy in the process of making machete}

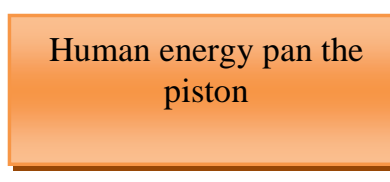

The air heat energy sekitar
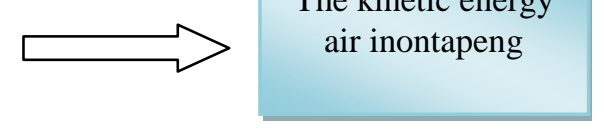

The kinetic energy air inontapeng

Heat energy on the iron

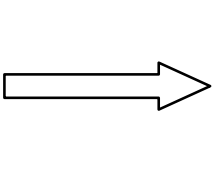

The kinetic energy of air in the small tube

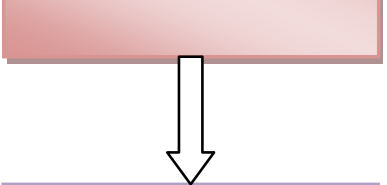

Heat Energy on the coals 


\section{c. Design instructional materials materials by teachers}

Mengonta Process (example and can be developed for other activities)

Table-1. The format of the design of learning materials science and mathematics by teacher

\begin{tabular}{|l|l|l|}
\hline $\begin{array}{l}\text { The form of the activity } \\
\text { and the phenomenon of } \\
\text { science }\end{array}$ & $\begin{array}{l}\text { The concept of science } \\
\text { related }\end{array}$ & Science Procedures \\
\hline & & \\
\hline & & \\
\hline
\end{tabular}

d. The Design of instructional activities for students

Table-2. The format of the design of the activities of student learning

\begin{tabular}{|l|l|l|}
\hline \multirow{2}{*}{$\begin{array}{l}\text { Forms of activity } \\
\text { instructional) }\end{array}$} & \multicolumn{2}{|l|}{ Student activities forms } \\
\cline { 2 - 3 } & Description of the phenomenon & $\begin{array}{l}\text { The identification of the concept and } \\
\text { description of the process of science }\end{array}$ \\
\hline & & \\
\hline
\end{tabular}

e. Some alternative learning science and mathematics about making machete (etc) traditional

- Inquiry Approach

- $\quad$ guided Inquiry approach (facilitated wrought iron)

A. Inquiry approaches to learning

- teachers and researchers brought groups of students to the location of the making of machete and instructed them to observe the process of making machete done by the smiths,

- Groups of children to observe the process of making machete, start from the process of "mengonta" until menebu.

- groups of students make machete, with the help of the smiths, (not to get the explanation of the process and the concept of science).

- student groups formulate the steps the process of making machete, and explain the process of science and the concepts of science and mathematics in every stage of the process of making machete

- students group discussion to improve the learning activities report

- students submit the results of the activities of group learning about the process of making machete

B. Guided Inquiry approach (facilitated machete maker)

- Teachers and researchers brought groups of students to the location of the making of machete and instructed them to observe the process of making machete done by the smiths,

- Groups of children to observe the process of making machete, start from the process of "mengonta" to "menebu".

- Groups of students make machete, with the help of the smiths,

- Students ask their observations or confirmation about the variation or differences that occur in a variety of activities from mengonta until menebu.

- Student groups formulate the steps making process of prang, and explain the process of science and the concepts of science and mathematics in every stage of the process of making machete

- Students group discussion to improve the learning activities report

- Students Submit the results of the activities of group learning about the process of making machete. 


\section{The results of the trial design of learning making machete traditional}

Table-3. Presents learning achievements (mastery of the concept of the context and the relationship with the concept of context) groups of junior secondary school students Christian Bellae in trial implementation of learning design making traditional machete. The study was conducted in January to March 2015.

Table-3. Mastery of concepts, context and relationship concepts in the context of making traditional machete

\begin{tabular}{|c|c|c|c|}
\hline Group & Mastery of the context & Mastery of the concept & $\begin{array}{l}\text { Mastery of relationships the } \\
\text { concepts of context }\end{array}$ \\
\hline A & 8,2 & 7 & 7 \\
\hline B & 8,5 & 7,4 & 7,6 \\
\hline C & 8,6 & 7,6 & 6,8 \\
\hline D & 7,8 & 7 & 7,6 \\
\hline
\end{tabular}

The data context is based on mastery ability groups formulate and explains the components and functions of component manufacturing machetes and function relationship between components. The mastery concept is based on the results of the evaluation of the task group and the ability to explain concepts, groups of variables and the relationships between variables in each section making machete as well as change energy from the process beginning to end process of making machete. Mastery of the relationship with the concepts of context based on the outline of the tasks and the explanation of the relationship between the function of the equipment and the process of making a machete with the phenomenon and concept as well as variables that can be measured or observed. The scale of the data used in the assessment of the task is $0-10$. The number of groups of students there are five people (groups A, B, D) and four people (Group C). In the task groups of students are welcome to communicate with facilitators (Blacksmith, teachers, parents and community leaders).

Application of design of trial results of learning making machete implemented outside of the regular classroom learning gives the conclusion:

1. Learning making machete very interesting for students are characterized by the presence in full activity, the task on time, initiatives are consulted in the task and asked at the moment of the observation process makes machete

2. The attitude of enthusiastic students can also be seen in the intensive group interaction and mutual help, do a reflection of task carried out group members

3. Mastering the context, concept, concept in the context of relationships can be categorized well enough for activities conducted in the four events, including a face-to-face initial explanation, observations, try yourself and fill in the form and describe the duties and tasks explained

\section{A. Approach To Inquiry Learning}

- teachers and researchers bring a student group to the site of the making of the machete and instruct them to observe the process of making hatchet performed by the Smiths

- groups of students to observe the making of machete, from the process of "mengonta" to menebu.

- groups of students did the activities make a machete, with the help of blacksmith (not to get an explanation of the process and the concept of science)

- groups of students to formulate the steps the process of making a machete, and explains the process of science as well as the concepts of science and math in every stage of the process of making machete

- $\quad$ student group discussions to improve reporting and learning activities

- groups of students submitting the results of group learning activities about the making of a machete. 
Table-4 Design instructional materials by teachers

The process of mengonta

\begin{tabular}{|l|l|l|}
\hline $\begin{array}{l}\text { The form of the activity } \\
\text { and the phenomenon of } \\
\text { science }\end{array}$ & $\begin{array}{l}\text { The concept of science } \\
\text { related }\end{array}$ & Science Procedures \\
\hline & & \\
\hline & & \\
\hline
\end{tabular}

Table-5 Design of instructional activities for students

The process of mengonta

\begin{tabular}{|l|l|l|}
\hline \multirow{2}{*}{$\begin{array}{l}\text { The form of } \\
\text { activities } \\
\text { (instructional) }\end{array}$} & Description of the phenomenon & $\begin{array}{l}\text { The identification of the concept and the } \\
\text { description of the process of science }\end{array}$ \\
\hline & & \\
\hline & & \\
\hline
\end{tabular}

\section{B. Guided Inquiry approach}

- teachers and researchers brought groups of students to the location of the making of machete and instructed them to observe the process of making machete done by the smiths,

- Groups of children to observe the process of making machete, start from the process of "mengonta" to "menebu".

- groups of students make machete, with the help of the smiths,

- students ask their observations or confirmation about the variation or differences that occur in a variety of activities from mengonta until menebu.

- $\quad$ student groups formulate the steps the process of making machete, and explain the process of science and the concepts of science and mathematics in every stage of the process of making machete

- students group discussion to improve the learning activities report

- students submit the results of the activities of group learning about the process of making machete.

\section{Directional Questions/Statements}

Table contains some statements on the column (2) which has a counterpart of the answers from the answer choices on the table- 6 . The choice the answer was written on the column (3) Table-7. There is the statement that the choice the answer more than one

Table 6. The process of making statements machete (etc)

\begin{tabular}{|c|l|c|}
\hline No & \multicolumn{1}{|c|}{ The statement } & The answer \\
\hline $\mathbf{1})$ & \multicolumn{1}{|c|}{$(\mathbf{2})$} & $(\mathbf{3})$ \\
\hline 1 & During the handle the piston in pull up, then occur: & $(6)$ \\
\hline 6 & During the handle the piston pushed into the bottom of the then occur: & $(2)$ \\
\hline 3 & The concept of SCIENCE/physics that occurs when the handle piston pressed & $(1)$ \\
\hline 4 & When the piston is pressed, coals of fire will increase light & $(4)$ \\
\hline 5 & Iron is buried in the coals become hot and finally red & $(10)$ \\
\hline 6 & Iron nailed/KBN RaharjoArjosiswoyo and can be changed in the form of for example more flat & $(7)$ \\
\hline 7 & $\begin{array}{l}\text { Iron that has been formed heated up and then plugged in the former oil fluid so that the iron } \\
\text { (macheteetc) become hardware }\end{array}$ & $(14),(3)$ \\
\hline 8 & $\begin{array}{l}\text { The experience of wrought iron stated that if the iron that has been formed into a machete } \\
\text { plugged in water will easily cracks than plugged in oil fluid }\end{array}$ \\
\hline
\end{tabular}

Table -7 Choice the answer from the statement on the table-6:

\begin{tabular}{|l|l|}
\hline No & Answer Choice \\
\hline 1 & Addition of oxygen will increase the burning of \\
\hline 2 & energy changes from human energy into energy air movement \\
\hline
\end{tabular}




\begin{tabular}{|l|l|}
\hline 3 & Used oil has boiling point $(>300 \mathrm{oC})$ is higher than the boiling point of water the \\
\hline 4 & air out from the small pipe attached at the base of the tube ontapeng, with pressure and high speed \\
\hline 5 & Energy of the wind in the same ontapeng with the energy of the wind in the small tube (songo) the \\
\hline 6 & Wind into the tube ontapeng from from the ends of the tubeontapeng \\
\hline 7 & $\begin{array}{l}\text { iron temperature changes all of a sudden cause changes in the structure of the iron molecule and iron became more } \\
\text { rigid/hardware }\end{array}$ \\
\hline 8 & Black oil fluid, while water colored nodes \\
\hline 9 & air in the piston increases the pressure of \\
\hline 10 & iron has changed the structure and become more software \\
\hline 11 & hot iron is cooled fowls so that the temperature is slowly down \\
\hline 12 & more severe oil fluid from the water of the \\
\hline 13 & multiplication wide cross tube with the speed of the wind is a constant \\
\hline 14 & water boil more quickly when the hot iron plugged while oil is the former slower \\
\hline
\end{tabular}

\section{The scheme changes energy in the process of making machete}

Below presented the parts from the scheme changes energy in the process of making machete. Boil the sequence changes energy according to the process of making suggestions, Give the arrow between the box that you row to show the sequence of the process of change of energy.

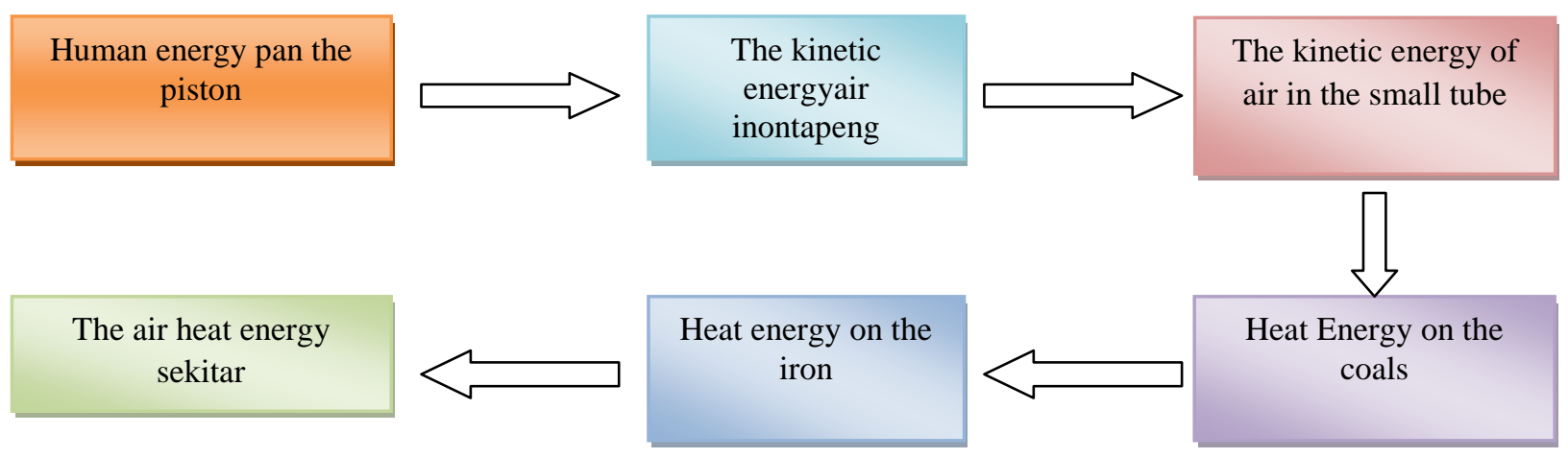

\section{Learning Process Evaluation Instrument:}

- learning process students are assessed using the indicator that process evaluation researchers thematic tasks

Table-8Product evaluation instrument learn (report/portfolio) (group) students

groups: .............

the execution date of activities: ...........

\begin{tabular}{|l|l|l|l|l|}
\hline no & $\begin{array}{l}\text { Stages of } \\
\text { activities }\end{array}$ & Treatment variations/phenomena & $\begin{array}{l}\text { The value of the } \\
\text { process science }\end{array}$ & $\begin{array}{l}\text { Value mastery of } \\
\text { concepts }\end{array}$ \\
\hline 1 & mengonta & Phenomenon: the wind into the large pipe & & \\
\cline { 3 - 5 } & & Speed variation mengonta & & \\
\hline & & & & \\
\hline
\end{tabular}

Table-9 Components of Science - Mathematics in the process of making the machete and the similar using traditional penanesaleng.

\begin{tabular}{|l|l|l|}
\hline No. & \multicolumn{1}{|c|}{ Stages } & \multicolumn{1}{|c|}{ The concept of sains- math } \\
\hline 1. & $\begin{array}{l}\text { Prepare a heap coal with little fire, placed in front } \\
\text { of lindungan. (stone ) }\end{array}$ & $\begin{array}{l}\text { A blacksmith do motion when preparing a pile } \\
\text { of coal . } \\
\text { lindungan ( stone ), coal and fire is a }\end{array}$ \\
\hline
\end{tabular}




\begin{tabular}{|c|c|c|}
\hline \multirow[b]{2}{*}{2.} & \multirow[b]{2}{*}{$\begin{array}{l}\text { Pump the wind in a pipe by pulling up then } \\
\text { pressing downward to the stem "piston ". The wind } \\
\text { is blowing through a small pipe ( songo ) toward a } \\
\text { heap take through lindungan so hot embers. }\end{array}$} & $\begin{array}{ll} & \text { component biology abiotic ( not live ) } \\
\text { fire and coals are components of physics } \\
\text { because both contain a heat }\end{array}$ \\
\hline & & $\begin{array}{ll}\checkmark & \text { The pressure on the pump that produces wind } \\
\text { (fluid) } \\
\checkmark \\
\text { Change energy of human resources became } \\
\text { energy motion of air } \\
\checkmark \\
\text { Multiplication cross sectional area pipe with } \\
\text { wind speed is constantkinetic energy (motion) } \\
\checkmark \quad \begin{array}{l}\text { a blacksmith that pumps wind in a pipe (use of } \\
\text { force) that requires effort }\end{array}\end{array}$ \\
\hline \multirow[b]{2}{*}{5.} & \multirow{5}{*}{$\begin{array}{l}\text { Take the iron to process into specific products, } \\
\text { input in the coals are burning. If needed add the } \\
\text { coals so that iron be covered coals } \\
\text { Pump back the air in ontapeng, until the iron } \\
\text { becomes red . } \\
\text { Take an iron bar that red already using tweezers of } \\
\text { iron, then a hammer above dangsilangese or } \\
\text { dangsilangbawine based on need } \\
\text { If the ax has become cold, input back iron in a heap } \\
\text { coal and pumps back the air in ontapengetc . Until } \\
\text { formed products iron need . } \\
\text { Heat back iron that had been formed, until reddish, } \\
\text { then dip to penanebuang, that contains oil former. } \\
\text { This process called menebu. Before menebu use } \\
\text { water. According to smiths, menebu uses oil safer } \\
\text { than menebu use water, because uses oil no metal } \\
\text { easily cracked. If using water, menebu to do } \\
\text { carefully and cannot be admit iron already formed } \\
\text { at the same time; if it is not iron would crack. }\end{array}$} & $\begin{array}{ll}\checkmark \text { Change in temperature at of iron is } \\
\text { displacement heat engine in conduction }\end{array}$ \\
\hline & & $\begin{array}{ll}\checkmark & \text { Pressure at the pumps and fire ( energy heat } \\
\text { engine ) who made a hot iron and becomes red } \\
\checkmark \quad \text { Air in a component chemistry is oxygen }\end{array}$ \\
\hline \multirow[t]{3}{*}{7.} & & $\begin{array}{ll}\checkmark & \text { Iron already red experienced piledrivers and } \\
\text { change form substance in physics and chemistry }\end{array}$ \\
\hline & & $\begin{array}{l}\text { Changes in temperature iron suddenly shifted } \\
\text { the molecular structure iron and iron into more } \\
\text { rigid / hard }\end{array}$ \\
\hline & & $\begin{array}{ll}\checkmark & \text { Transmission fluid heavier than water } \\
\checkmark & \text { Water faster boiling as a hot iron inserted while } \\
& \text { oil former slower } \\
\checkmark & \text { Oil former having the boiling point }\left(>300^{\circ} \mathrm{C}\right) \\
& \text { higher than the boiling point of water }\left(100^{\circ} \mathrm{C}\right)\end{array}$ \\
\hline
\end{tabular}

\section{Conclusion And Suggestion}

\section{A. Conclusion}

1. Function participatory community forum learning to be developed for quarrying, design and facilitating the draft based learning local wisdom. Potential participatory community forum be involved in by the school cooperate with the lecturer or researcher from college.

2. Natural phenomena or activity people can designed and developed as part of learning science and math at school.The environment, both natural phenomena and social and cultural could be designed as of matter learning (, integrated science mathematics, and the implications) social and potentially to build: knowledge,skill and attitude.

3. The development of matter and learning is essential community based in education / learning because confronting students with the, experience and real needs experienced in the life of daily.Students have 
motivation high in studying the relations between the context in the environment with information and matter learning obtained in class.

\section{B. Suggestion}

1. Schools should adopt and develop matter learning that environmental based around because the potential for development process of science a complete (observe, measuring, hypothesize, analyzing etc ).An example of this matter and learning activities this to be a model for development learning by schools.

2. Teachers and schools should be active rally source of learning outside school, especially public participation. Investors activities in society can be used as informants or facilitators study in facets

3. Teachers Working with researchers (lecturers and students) should continue to develop learning materials sourced from the environment around the students, because this may provide gains against the materials and learning activities in the school

\section{References}

1. Atilla ÇIMER,2007.Effective Teaching in Science: A Review of Literature.Journal ofTurkish Science EducationVolume 4, Issue 1, May 2007http://www.tused.org

2. Creswell,John W.2008. Educational Research Planning, Conducting, and Evaluating Quantitative and Qualitatif Research. Pearson Education, Upper Saddle River. New Jersey

3. Hamalik, Oemar. 2005. PerencanaanPengajaranBerdasarkanPendekatanSistem. Jakarta: BumiAksara.

4. Higgins. P. 2002. Outdoor education in Scotland. Journal of Adventure Education and Outdoor Learning, 2 (2): 149-168:

5. Joyce, B., \& Weil, M. 1980. Model of teaching. New Jersey: Prentice-Hall, Inc.

6. Mahoney J. L., Lord H. and Carryl E. 2005. An ecological analysis of after-school program participation and the development of academic performance and motivational attributes for disadvantaged children. Child Development, 76, 811-825.

7. Medellu Ch. 2013. Surveikesiapan guru merancangdanmengimplementasikanpembelajaran yang materinyadiangkatdarilingkungansekitar. JurusanFisika, Unima.

8. Mikulec, Erin,McKinney, Kathleen. 2014. Perceived learning outcomes from participation in one type of registered student organization: Equestrian sport clubs. Journal of the Scholarship of Teaching \&Learning. Sep2014, Vol. 14 Issue 3, p93-109. 17p

9. Mulyasa. 2004. Become A Professional Teacher. Bandung: RemajaRosdaKarya

10. Popov O. 2008. Developing Outdoor Physics Project Using Activity Theory Framework. http://www.divaportal.org/smash/get/diva2:318676/FULLTEXT01.pdf. Download: 22 Pebruary 2013

11. Sugiyono,2008. Educational Research Methods Quantitative Approach, Qualitative and $R \& D$. Alfabeta. Bandung

12. Tumangkeng J. 2013. The survey report for the development of a participatory community model in the development of thematic learning in Sangihe.Physics Department Faculty of Math and ScienceManado State University 